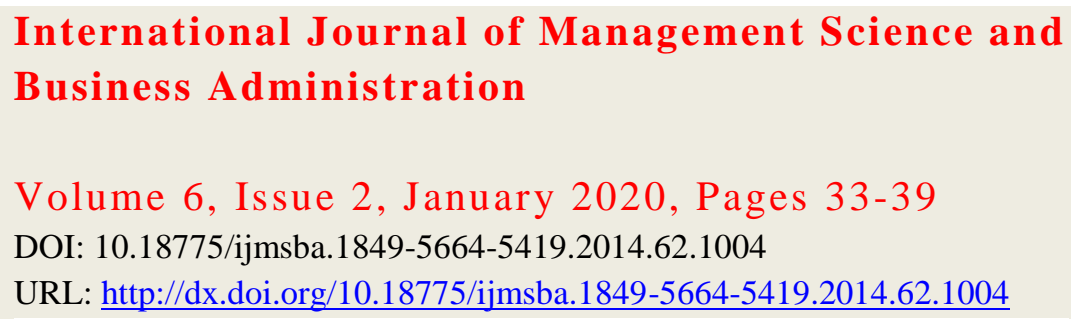

\title{
Theoretical Features of FDI (Foreign Direct Investment) and its Influence to Economic Growth
}

\author{
Gavkhar Bekmurodova \\ Tashkent State University of Economics, Tashkent, Uzbekistan
}

\begin{abstract}
There are numerous positive effects of Foreign Direct Investment (FDI) influencing on both the micro and macro levels. The purpose of this research is to identify and analyze management approaches to attract FDI. The study is aimed to offer a basis for future empirical investigation into FDI attraction and FDI intentions at the structural level. FDI influences significantly on the economic growth of the host country and the constancy of its macroeconomic performance. A methodical approach providing a solid base for empirical research is defined. In this systematic approach, research design, measurement tool development, data collection and preparation are included.
\end{abstract}

Keywords: FDI, Economic growth, Long-term investment, Short-term investment, Business environment, Investors, Doing business

\section{Introduction}

It is evident that from the experience of world economy, Foreign Direct Investment (FDI) has been attributing to the economic improvement. Foreign Direct Investment effects through not solely on the capital of the host country, but also makes attempts to obtain access to new markets, acquire latest technology and expertise (Papanicolau, Booth and Neumeier, 2010), as well as to create incomes (Booth, Königer and Nunnenkamp, 2010; Kumar and Siddhartan, 2013). FDI leads to find feasible solutions for a variety of problems. FDI provides valuable capital in order to arouse economic growth and development and brings technology along with knowledge. Additionally, new markets around the world can be more accessible due to FDI. In fact, several factors such as how knowledgeable and skillful staff is and productivity aspects influence considerably on attracting and maintaining foreign direct investment (Monaghan, 2012).

Numerous countries in the world are currently focusing more on to attract and facilitate foreign investment. Governments implement some policies constantly such as economic integration policies, investment strategies and measures to ensure that the engine of real economic development in the industrial sector continues to work. The concept of this study has been designed for a more specific analysis of FDI contribution to socio-economic and technological development. Indicators like formation of a broader strategy and measures to improve macroeconomic conditions, personnel skills, and infrastructure serve to promote enterprise development. For all these measures to be more visible and tangible FDI is very important and countries need to know good use of it. Main purpose of the investor on bringing direct investment is to generate profits (UNCTAD, 2012). According to UNCTAD in the recent years, there is a significant trend with a flow of foreign direct investment; these are two essential ones. The first is that the figures for the amount of foreign direct investment is declining in developed countries and moving to developing countries contributing to its increase.

\section{Literature Review}

In order to have a true understanding of economic impact of FDI, it is vitally important to study what are the main reasons for both investors and FDI receivers while they work on investment projects. The literature review makes a distinction between three main types of investment motivations including resource-seeking, market-seeking, and efficiency seeking (Dunning, 1993). Resource seeking FDI is classified by accessibility of natural resources, inexpensive labor and infrastructure in the host country (Morck, 2008). Regarding the market seeking FDI, it is characterized by an eagerness of investors to enlarge their businesses to overseas. Market-seeking FDI, in most cases ensues in well protected sectors. An importance of efficiency-seeking FDI is crucial when a company has an intention to gain common governance of the 
dispersed activities geographically through both resources seeking and markets seeking types of FDI (Ismail, 2015). A key motive for efficiency-seeking FDI is that open cross-border markets should be available so as to make efficiencyseeking FDI occur.

When we take a look at hosting countries receiving FDI, these countries are required to have two essential motives. Firstly, there is a scarcity of internal resources in the FDI receiving countries to serve their own local markets. This usually happens with poor countries, where the income is considerably low. Second reason is that, expertise and technologies are not sufficient enough in host countries (Kemme, 2002). Due to the availability of gas, oil, and metal, FDI in most cases, takes place in Central Asia.

Too much uncertainty is the natural enemy of long-term investment. Frequent upheavals in the marketplace or uncertainty about the terms and directions of competition add a significant element of risk to longer-term business decisions, which drives companies to seek recovery of their investments in the shorter period of time and dampens investment in activities that, by their very nature, will take substantial time to come to fruition. Federal, state, and local governments play a crucial role in the affairs of industry. The policies, routines, and practices of governments can either improve or erode predictability (decrease or increase risk) in markets and technologies and thereby determine whether an environment is conducive or inimical to long-term investment.

Developing countries, emerging economies and countries in transition have come increasingly to see FDI as a source of economic development and modernization, income growth and employment. Countries have liberalized their FDI regimes and pursued other policies to attract investment. They have addressed the issue of how best to pursue domestic policies to maximize the benefits of foreign presence in the domestic economy. The article attempts primarily to shed light on the second issue, by focusing on the overall effect of FDI on macroeconomic growth and other welfare-enhancing processes, and on the channels through which these benefits take effect. The overall benefits of FDI for developing country economies are well documented. Given the appropriate host-country policies and a basic level of development, a preponderance of studies shows that FDI triggers technology spillovers, assists human capital formation, contributes to international trade integration, helps create a more competitive business environment and enhances enterprise development. All of these contribute to higher economic growth, which is the most potent tool for alleviating poverty in developing countries. Moreover, beyond the strictly economic benefits, FDI may help improve environmental and social conditions in the host country by, for example, transferring "cleaner" technologies and leading to more socially responsible corporate policies.

The report does not focus solely on the positive effects of FDI for development. It also addresses concerns about potential drawbacks for host economies, economic as well as non-economic. While many of the drawbacks, referred to as "costs" in this report, arguably reflect shortcomings in the domestic policies of host countries, important challenges may nevertheless arise when these shortcomings cannot easily be addressed. Potential drawbacks include a deterioration of the balance of payments as profits are repatriated (albeit often offset by incoming FDI), a lack of positive linkages with local communities, the potentially harmful environmental impact of FDI, especially in the extractive and heavy industries, social disruptions of accelerated commercialization in less developed countries, and the effects on competition in national markets. Moreover, some host country authorities perceive an increasing dependence on internationally operating enterprises as representing a loss of political sovereignty. Even some expected benefits may prove elusive if, for example, the host economy, in its current state of economic development, is not able to take advantage of the technologies or knowhow transferred through FDI.

\subsection{Trends}

The magnitude of FDI flows continued to set records through the last decade, before falling back in 2001. In 2000, world total inflows reached 1.3 trillion US dollars (USD) - or four times the levels of five years earlier. More than $80 \%$ of the recipients of these inflows, and more than $90 \%$ of the initiators of the outflows, were located in "developed countries". The limited share of FDI that goes to developing countries is spread very unevenly, with two-thirds of total FDI flows from OECD members to non-OECD countries going to Asia and Latin America. Within regions there are some strong concentrations on a few countries, such as China and Singapore in the case of Asia. Even so, FDI inflows represent significant sums for many developing countries, several of them recording levels of FDI, relative to the size of the domestic economy, that overshadow the largest OECD economies. Moreover, the flow of FDI to developing countries 
worldwide currently overshadows official development assistance by a wide margin, further highlighting the need to address the use of FDI as a tool for economic development.

\subsection{FDI and Growth}

Beyond the initial macroeconomic stimulus from the actual investment, FDI influences growth by raising total factor productivity and, more generally, the efficiency of resource use in the recipient economy. This works through three channels: the linkages between FDI and foreign trade flows, the spillovers and other externalities vis-à-vis the host country business sector, and the direct impact on structural factors in the host economy. Most empirical studies conclude that FDI contributes to both factor productivity and income growth in host countries, beyond what domestic investment normally would trigger. It is more difficult, however, to assess the magnitude of this impact, not least because large FDI inflows to developing countries often concur with unusually high growth rates triggered by unrelated factors.

Whether, as sometimes asserted, the positive effects of FDI are mitigated by a partial "crowding out" of domestic investment is far from clear. Some researchers have found evidence of crowding out, while others conclude that FDI may actually serve to increase domestic investment. Regardless, even where crowding out does take place, the net effect generally remains beneficial, not least as the replacement tends to result in the release of scarce domestic funds for other Investment purposes. In the least developed economies, FDI seems to have a somewhat smaller effect on growth, which has been attributed to the presence of "threshold externalities". Apparently, developing countries need to have reached a certain level of development in education, technology, infrastructure and health before being able to benefit from a foreign presence in their markets. Imperfect and underdeveloped financial markets may also prevent a country from reaping the full benefits of FDI. Weak financial intermediation hits domestic enterprises much harder than it does multinational enterprises (MNEs). In some cases, it may lead to a scarcity of financial resources that precludes them from seizing the business opportunities arising from the foreign presence. Foreign investors' participation in physical infrastructure and in the financial sectors (subject to adequate regulatory frameworks) can help on these two grounds.

Host countries' ability to use FDI as a means to increase exports in the short and medium term depends on the context. The clearest examples of FDI boosting exports are found where inward investment helps host countries that had been financially constrained make use either of their resource endowment (e.g. foreign investment in mineral extraction) or their geographical location (e.g. investment in some transition economies). Targeted measures to harness the benefits of FDI for integrating host economies more closely into international trade flows, notably by establishing export-processing zones (EPZs), have attracted increasing attention. In many cases they have contributed to a raising of imports as well as exports of developing countries. However, it is not clear whether the benefits to the domestic economy justify drawbacks such as the cost to the public purse of maintaining EPZs or the risks of creating an uneven playing field between domestic and foreign enterprises and of triggering international bidding wars.

\section{Methodology}

In regards to the method of survey research, respondents will be asked to answer questions administered through questionnaires. A specific system is mainly focused during the survey particularly on companies, joint stock companies, and governmental organizations will be evaluated and analyzed. Moreover, the aim is to endeavor and capture an outline of the present circumstance in the wide-ranging market in Uzbekistan. With the results of questionnaires, valuable data about various joint stock companies and governmental organizations in Uzbekistan can be accumulated, which are seeking potential investors and foreign direct investment from both foreign and local countries.

\section{Analysis}

The Chamber of Commerce and Industry of Uzbekistan (CCIUz) in cooperation with the Joint Stock companies of Uzbekistan considers inviting foreign companies and investors to purchase manufacturing enterprises in industrial sectors and financial institutions to further support of attracting foreign investments in various industrial sectors of Uzbekistan. In this regard, the CCIU would like to offer purchasing not less than $15 \%$ shares of joint stock companies and commercial banks in accordance with Presidential Decree "On additional measures to attract foreign investors to joint stock companies” №2454 dated on 21.12.2015, the list of joint stock companies has been approved accordingly. 
The list of Joint Stock Companies includes following sectors:

- commercial banks - 18

- insurance companies - 7

- energy sectors - 14

- oil and gas industry - 40

- construction sectors - 6

- chemical industry - 16

- pharmaceutical industry - 6

- automobile and railway - 33

- electronics industry - 9

- cotton industry and textile industry - 38

- others -60

Hence, the CCIUz expresses its readiness to assist foreign companies and potential investors in providing information on the activities of each of the abovementioned companies, to conduct negotiations on the subject of potential acquisition of listed companies. The CCIUz is also ready to organize visits to the companies of interest, provide other organizational, legal services and appropriate information on the investment environment.

\section{Economic Indicators of Uzbekistan Sustainable Economic Growth}

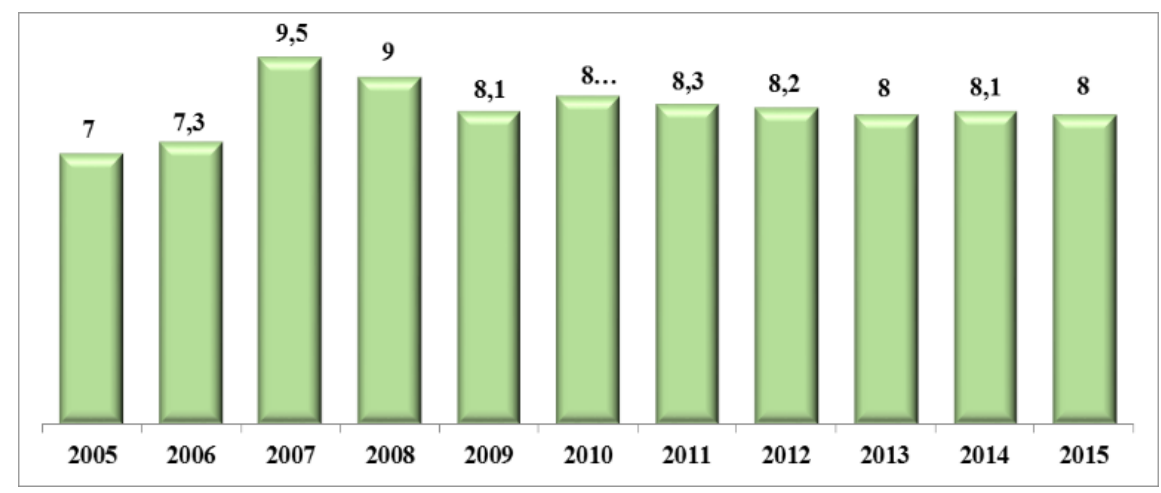

Figure 1: GDP growth rate (in \% to previous year)

- Uzbekistan is among top 5 fastest growing economies in the world.

- GDP has increased 4.1 times during the years of independence;

- Sustainable high rates of economic growth retain at the level not less than $8 \%$ annually for the last years; (in million. USD)

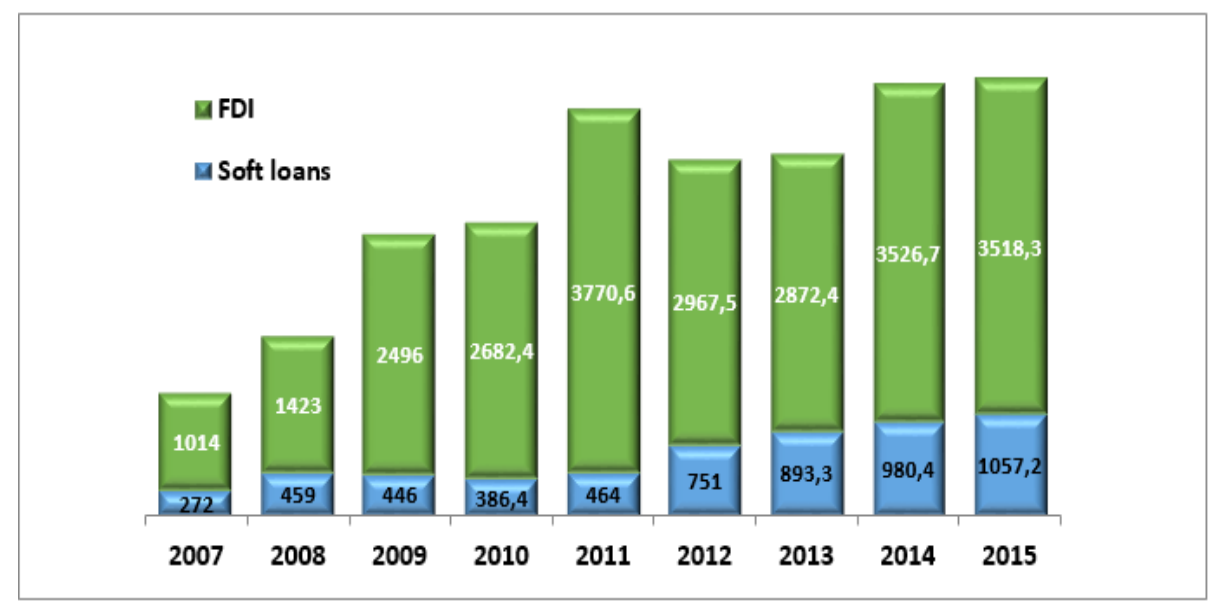

Figure 2: Foreign Investments Growth in Uzbekistan 
- According to the World Bank "Doing Business" report for 2019, globally Uzbekistan stands at 76 in the ranking of 180 countries.

- Uzbekistan is in top ten countries that improved the indicator of the quality of the regulatory environment for business.

- This indicator in a less degree depends on the changing of the ranking of other countries, and better reflects the progress, reached by a separate country.

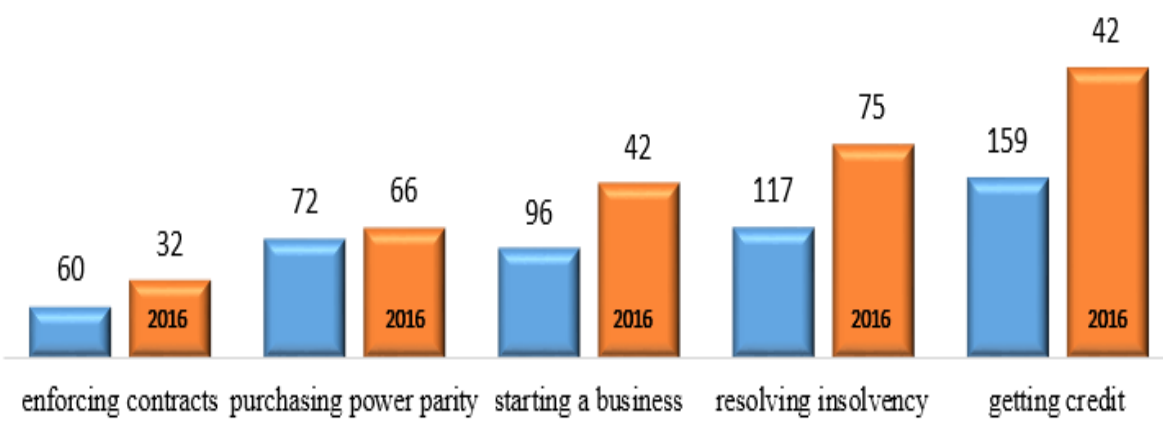

Figure 3: Doing Business report ${ }^{1}$

Over the last 4 years, Uzbekistan has gained numerous success in various spheres. Especially, investment projects and laws to improve investment activities have significantly been worked out. Environment for investors to start their business in local companies and firms has been created. It is obvious by the information being presented on popular international reports like Doing Business, World Investment Report and many others. According to the UNCTAD's 2018 World Investment Report, FDI inflows slightly decreased drastically in 2017 to USD 96 million. The World Bank also claims investment growth moderated from $9.5 \%$ in 2016 to $7.1 \%$ in 2017 . This represents a $27.82 \%$ drop from 2016 levels (133 million), but strong investments in renewable energy anticipate a much stronger FDI outlook going forward (444\% FDI increase from 2017 to 2018) (FDI Intelligence). FDI traditionally arrives from Russia, South Korea, China and Germany, but Canada increased its financial presence in 2018. Investments focus on the energy sector, including alternative/renewable energy in recent years. Total FDI stock of FDI stood at USD 9.3 billion (13.5\% of GDP) in 2017. Uzbekistan ranked 76th in the World Bank 2019 Doing Business, including a ranking as the 12th easiest country to start a business in. The country also ranks 158th out of 180 countries in Transparency International's Corruption Perceptions Index 2018. The Government's policy of establishing seven special economic zones with tax breaks for investors has made the country attractive to international capital. Examples include the Syrdaryo economic free zone and an October 2018 decree by Interim President Shavkat Mirziyoyev requesting "additional measures for the intensification and expansion of activities of free economic zones" (FDI Intelligence). Uzbekistan also sold up to USD 300 million in Eurobonds during 2018 to be used production and infrastructure projects (Bloomberg). Russia has approached Saudi Arabia and Uzbekistan to construct a nuclear plant in these countries through Rosatom, Russia's nuclear corporation (TASS). USD 2.7 billion in money transfers from Russia to Uzbekistan was reported by the Russian central bank in 2017. (Reuters). Restructuring of large state enterprises and joining the WTO would bolster Uzbekistan's plea for FDI, but the country has been slow to advance on said fronts (Reuters).

\section{Discussion of the Results}

A favorable investment atmosphere needs to be generated as a means to involve more investment countries. In this circumstance, reforms purposed on creating an environment for political decision-oriented investment have an important role to play. Along with the investment climate considered as key to economic growth, it is also an essential determinant how globalization is influencing domestic customers. There are enforcement practices and specific circumstances cited in the article. Additionally, the benefits of FDI were indicated clearly. Novelty of this study is that it builds on previous research and synthesizes strategies designed to attract foreign direct investment. The results propose that government officials working in the sphere of FDI should create and implement policies which are facilitating FDI. Together with the other determinants which the research identified a promising environment foreign direct investment can be generated. We propose a future study is conducted which would assess the impact of these determinants and strategies on FDI in a specific context of a region, country or city.

\footnotetext{
${ }^{1}$ http://www.chamber.uz/en/page/4833t
} 
Unlike and the traditional models of coordination, the above model depicts coordination as technology mediated. Moreover, in contrast to the traditional models, we allow for two-way causality between these variables, as coordination mechanisms not only manage existing interdependencies, but they can also elicit specific interdependencies, particularly those connectivity- and communication-related, as they are needed for inducing all parties to follow the overall or common goal. Finally, we look at dimensions - and not patterns - of interdependencies in recognition that interdependencies are a multifaceted phenomenon. In contrast to early models, typically prioritizing coordination mechanisms, we see these mechanisms as partial and complementary in their pursuance of coordination.

\section{What to consider if you invest in Uzbekistan}

\section{Strong Points}

Uzbekistan's key assets attracting FDI include:

- abundant and diversified natural resources (gas, gold, cotton, hydropower potential);

- low level of debt and comfortable foreign exchange reserves;

- ambitious public investment program;

- important size of the domestic market (population of 32 million)- strategic position between China and Europe ("New Silk Road").

Weak Points

The major obstacles to FDI in Uzbekistan are:

- low economic diversification and dependence on commodity prices;

- low competitiveness;

- underdeveloped banking sector;

- state interventionism and difficult general business climate;

- autocratic regime.

To improve the business environment, the Government of Uzbekistan introduced in 2017 a number of legislative changes, including the cancellation of unscheduled, and seemingly arbitrary or punitive, inspections of businesses as of January 1, 2017; elimination of the requirement to convert certain percentages of hard currency export earnings at the official (artificially low) exchange rate; simplification of business registration procedures; creation of a Business Ombudsman office; and a Law on Countering Corruption that attempts to increase transparency in Government of Uzbekistan functions.

By law, foreign investors are welcome in all sectors of the Uzbek economy and the government cannot discriminate against foreign investors based on nationality, place of residence, or country of origin. However, government control of key industries has discriminatory effects on foreign investors. For example, the Government of Uzbekistan retains strong control over all economic processes and maintains controlling shares of key industries, including energy, telecommunications, airlines, and mining. The government still regulates investment and capital flows in the raw cotton market and controls all silk sold in the country, dampening foreign investment in the textile and rug-weaving industries. Partial state ownership and government influence are common in many key sectors of the economy. The state still reserves the right to export some commodities, such as nonferrous metals and minerals. In theory, private enterprises may freely establish, acquire, and dispose of equity interests in private businesses, but in practice, this is difficult to do because Uzbekistan's securities markets are still underdeveloped. Investment programs were launched in order to encourage big investments in the priority sectors. Programmes include 86 foreign direct investment projects totaling 1.8 billion dollars, of which more than half is for the energy sector. To encourage foreign investment, the Government provides tax incentives to joint stock companies for which foreign investment participation accounts for at least $15 \%$ of the authorized capital.

\section{Conclusion}

The main policy conclusion that can be drawn from the study is that the economic benefits of FDI are real, but they do not accrue automatically. To reap the maximum benefits from foreign corporate presence a healthy enabling environment 
for business is paramount, which encourages domestic as well as foreign investment, provides incentives for innovation and improvements of skills and contributes to a competitive corporate climate.

\section{References}

- Abdurashitovna, Nasritdinova Gulchehra. "FDI Scenario in Uzbekistan: Current Reforms and Future Prospects." International Journal of Management Science and Business Administration 4, no. 4 (2018): 38-42. Crossref

- Bah, A. O., Kefan, X., \& Izuchukwu, O. O. (2015). Strategies and Determinants of Foreign Direct Investment (FDI) Attraction. International Journal of Management Science and Business Administration, 1(5), 81-89. Crossref

- Brigida, M., \& Madura, J. (2012). Sources of target stock price run-up prior to acquisitions. Journal of Economics and Business, 64(2), 185-198.

- Dornean, A., Işan, V., \& Oanea, D. C. (2012). The impact of the recent global crisis on foreign direct investment. Evidence from central and eastern European countries. Procedia Economics and Finance, 3, 1012-1017. Crossref

- Dunning, J. H. (1994). Reevaluating the benefits of foreign direct investment.

- Madura, J. (2011). International financial management. Cengage Learning.

- Monaghan, S. (2012). Attraction and retention of foreign direct investment (FDI): The role of subnational institutions in a small, highly globalised economy. Irish Journal of Management, 31(2), 45.

- Morck, R., Yeung, B., \& Zhao, M. (2008). Perspectives on China's outward foreign direct investment. Journal of International Business Studies, 39(3), 337-350. Crossref

- Pilat, D. (2003). ICT and economic growth: evidence from OECD countries, industries and firms. OECD Publishing.

- Sodikov, Z (2013). The influence of modern technologies on economic development. Conference Proceedings: principles of Corporate Governance, Tashkent, Uzbekistan, 25-26.

- SPECIAL FOCUS ON THE BOARD'S SUPERVISORY ROLE COMPARED WITH GERMAN PRACTICE. Corporate Board: Role, Duties \& Composition / Volume 10, Issue 3, 2014

- Suyunov, D, (2007). The mechanism of corporate governance: The problems and solutions, Journal of Corporate Governance.

- Tara, Sh., and Sadri, S (2015) Corporate Governance and Risk Management: An Indian Perspective. International Journal of Management Science and Business Administration Volume 2, Issue 3, 7 - 16 Crossref

- Troschke, M. and Zeitler, A. (2006), Privatisation and corporate governance in Kazakhstan and Uzbekistan: insights from a corporate survey in food and light industries, Osteuropa-InstitutMünchen, Working Paper No.256 Worldbank. Org (2016). Uzbekistan statistics

- Yussof, I., \& Ismail, R. (2002). Human resource competitiveness and inflow of foreign direct investment to the ASEAN region. Asia-Pacific Development Journal, 9(1), 89-107. 